\title{
Capstone Project Based Experiential Learning - Case of Institute of Business Management (IoBM)
}

\author{
Marium Mateen Khan \& Mohammad Ekhlaque Ahmed
}

Marketing Department, Institute of Business Management, Karachi Pakistan

Correspondence should be addressed to: Mohammad Ekhlaque Ahmed; ekhlaque.ahmed@iobm.edu.pk

Received date: 8 August 2017; Accepted date: 22 November 2017; Published date: 27 February 2018

Academic Editor: Ching Sock Lee

Copyright ( 2018. Marium Mateen Khan \& Mohammad Ekhlaque Ahmed. Distributed under Creative Commons CC-BY 4.0

\begin{abstract}
The case study aims to highlight the importance, process and framework of the Capstone Project Course (Experiential Learning) that has been initiated by Institute of Business Management (IoBM). The case provides detailed analysis of how the Project is executed by the students under the guidance of the Faculty and industry supervisors assigned to each group of students. The project entails various methods to monitor the performance of the task at hand and the students input and efforts in the duration of both Capstone 1 and Capstone 2 Projects ( 3 credit hours each). This initiative taken by the university highlights the different aspects of experiential learning processes and how they benefit the academia as well as the company in the industry. It is a cost free project carried out by students to enhance their learning and exposure into the corporate sector first hand. This kind of projects from multiple disciplinarians has proven to be a milestone for the students and the University in learning with concrete outcomes for the industry as a whole.
\end{abstract}

Keywords: Capstone Assessment, Experiential Learning, Capstone Circular, Capstone Pathway

\section{Introduction}

The word Capstone is used for a final achievement which is built upon the past works and encircles those past works.
Capstone projects are often included in engineering curricula in order to integrate functional, operational and other multidisciplinary areas. Capstone projects are also used to inculcate professional skills

Cite this Article as: Marium Mateen Khan \& Mohammad Ekhlaque Ahmed (2018)," Capstone Project Based Experiential Learning - Case of Institute of Business Management (IoBM) ", Journal of e-Learning and Higher Education, Vol. 2018 (2018), Article ID 412705, DOI: 10.5171/2018.412705 
amongst the students, which are difficult to impart in a traditional form of lecture based class or a course (Ward, 2013).

According to Ward (2013), Capstone projects serve as a medium that facilitates students in transitioning from academic phase to a professional life. Such projects have a direct effect on the university's ranking and reputation in the industry and its students' employability. Hence, it is worthwhile to introduce and continue such experiential learning projects at university level.

Capstone projects are designed in a way that encompasses all the areas and aspects of an undergraduate student's experience through the application of student's skills and breadth of knowledge learned throughout the undergraduate program. The aim behind these projects is to develop the students and their skills for their professional career. Capstone projects aim to develop students skills which include; multi-disciplinary teamwork, application of theory, data interpretation, problem solving, design, communication skills, and ethics. Generally, these objectives are specified in the outcomes of the program and for the university's assessment for accreditation (Ward, 2013).

Successful and effective capstone projects are of immense value to the employers, as they rely on these projects to equip the graduates with knowledge, skills and experience to bring success to their respective organizations. Hence, it is important to enlist the elements that contribute towards the success and effectiveness of a capstone project (Ward, 2013). Howe and Wilbarger (2005) documented such elements for engineering capstone projects, which include; duration, faculty involvement, organizational structure, funding sources, project sourcing and industry sponsorship. These elements can be used by other universities belonging to other domains around the world.

\section{Capstone Business Curricula}

Mintzberg, (2004) asserted that the professors who teach MBAs overemphasize the sciences of management while ignoring its art. Mintzberg, (2004) argues that after graduation MBA students have inflated views about their ability and competence to be successful. He emphasizes that for effective management many essential skills can only be learned through the personal experience and suggested major changes in the management education which will encompass more experience based learning before a student graduates and transitions to a professional life.

Kolb \& Fry (1974) developed an experiential learning model based on four elements; concrete experience, observation and reflection, formation of abstract concepts, and testing in new situations. They argued that the learning cycle can begin at any one of the four points. Thus, the model should be envisioned as a continuous spiral.

In the model given in Figure 1, two important aspects can be seen; the use of concrete experience for testing ideas and the use of feedback in order to change theories and practices Kolb, (1984). The model emphasizes that experience plays a vital role in learning Smith, (2001). Some of the critics have argued that the model given by Kolb is too simplistic. However, Tennant (2006) stated that the framework provides an excellent guideline for planning of teaching and learning activities.

\section{Incorporating Job Shadowing into a Business Course}

According to McCarthy and McCarthy (2006), in order to follow the experiential model, business programs should begin with job shadowing. However, Paris and Mason (1995) defined job shadowing as an option to gain a work experience where students learn about a job by walking through the work day as a shadow of a competent worker. Job shadowing is a work experience that is temporary, unpaid exposure to the 
workplace in an occupational and functional area of interest for the student. Students get to witness firsthand work environment, employability and occupational skills in practice, the value of professional training and potential career options. Job shadowing is designed to increase career awareness, help in modelling student behavior through examples and reinforce in the student the link between classroom learning and work requirements. Almost any and every workplace is a potential job shadowing site.

\section{Capstone Project Course at Institute of Business Management (IoBM) - Methodology}

The objective of Capstone Project Course at IoBM is to provide the students of MBA program, an opportunity to work on real world issue and connect it with the conceptual framework using the most modern management tools. The project engages the students with real world complexities and helps them enhance their competencies and skills related to strategic thinking, communication, managing information and choosing among alternatives.

Projects on corporate issues involving multiple functional areas e.g., marketing, finance, supply chain, operations etc. are provided by the industry experts and the students carry out those projects. The level of efforts required by each project is at least 900 man-hours for each group comprising 5 students. Each students group is assigned a faculty supervisor that becomes a liaison between the academia and the industry and to support and guide the students throughout the project.

After the project has been completed, a presentation is given to the top management of the firm from which the project came. During the presentation, students provide their insights to the top management along with their recommendations. In many firms, those suggestions and recommendations have already been implemented or are in the process of being implemented. The evaluation of the work done by the students is not just in the hands of the faculty supervisor but also in the hands of the industry expert.

\section{Initial Capstone Pathways}

The Capstone project consists of two initial pathways that are provided to the students i.e. firstly, an Organization oriented Projects, wherein the company from various industries is approached to identify the cross functional issue for the students to study, analyze and recommend alternative solutions through guidance. The second Pathway includes an industry Research Projects where students are involved in the identification and selection of a significant industry topic with practical applications in multiple organizations. These industry research studies revolve around the dimensions of the progress made in Pakistan and through facilitations by Faculties; the data gathered would conclude consolidated results.

The project is monitored through different methods which include documents and Forms to be filled on a regular basis or the number of times the students visit the corporations. Some of the documents entail Capstone Logging forms, Capstone checklists and Capstone Project Plan on how it would be executed with the prescribed timeline. This helps in record keeping of the project for both the Organization and the University (See Annexure 1).

\section{Steps for Initiation of a Capstone Project}

In order to receive a project from a company, the following steps are carried out:

1) Sending of invitation for capstone project to a company (Annexure 1)

2) Receiving a feedback from the company about the project

3) Arranging a meeting with the top management of the company 
4) Acquiring project from the company; company fills the registration form (Annexure 2)

5) Registration of students for Capstone project course

6) Formation of student groups for the project (3-5 members, depending on the project)

7) Allocation of projects to the student groups based on their specialization (subject majors)

8) Providing a faculty supervisor to each group to act as a monitor and liaison

9) First meeting of the student group with the company/industry supervisor who will be monitoring the project progress

10) In the first meeting briefing is given about what the company expects from the students and what is desired by the end of the project is required. The company provides the list of deliverables and deadlines to the students

11) Students start working on the allocated tasks, and weekly updates are provided to the company. Students are constantly in touch with the company and make changes as per the feedback of the company (Annexure 3)

12) After all the deliverables are completed, a final presentation is made by the students on the analysis of their findings. The presentation is first delivered to the Capstone project lead and the Dean. After approval from both, after changes if required, the presentation is given to the top management of the company that gave the project

13) After the completion of many projects, the findings and recommendations are implemented by the companies

14) Many companies gave more projects after the completion of the first project. Some companies extended the project to second phase as well
15) Students of the projects were also provided with a job offer by some of the companies

\section{Assessment and Grades}

Capstone Projects are executed through three hour per week sessions with the assigned supervisors at a scheduled time and day of the week. Attendance of these sessions is recorded which helps students to discuss their weekly progress of the project at hand. These sessions may also include lectures, peer reviews, student presentations and onoto-one clinics with academic staff. The combinations of these sessions conclude with a refined problem which may need further exploration and establishment. The analysis of the data and a well-argued based report is presented which addresses the company's specific/ industry related problems. At the end of the semester, a grade is assigned to the student with regard to their performance in the project in both Capstone 1 and Capstone 2.

Details on the assessment as rubrics are provided and discussed by the Faculty Supervisor at the beginning of the course to give students information before commencing the project. Each group will establish a portfolio that would contain all the project artifacts related to the entire duration of the project consisting of (but not limited to) proposal, plans, interim progress reports, notes on each individual item referred in secondary research, scheduling and notes of all primary research activities such as pictures, screenshots, transcripts, sketches of incremental development of ideas, and preliminary results and other analyses.

Grades are given by the faculty $(60 \%)$, Head of department (20\%) and industry supervisor (20\%). Assessment forms used in this regard are given in Annexure 5.

Capstone project course started in the summer of 2015 at IoBM. In the first semester, IoBM received 9 projects from 
different companies belonging to different industries. Students were able to carry out all 9 projects successfully. In the next semester (Fall 2015), IoBM received 19 projects in total. Some companies gave more than one project during this semester, while some companies extended their projects for second phase by the IoBM students. From then onwards, IoBM has done over 100 projects with more than 50 national and international companies (See Annexure 6 for List of Sample Projects).

\section{Corporate Feedback}

The industry supervisors were a part of the projects given by their companies and played the counterpart role of the faculty supervisor in monitoring the project progress throughout the project. After the projects were finished at the end of each semester, industry experts highly appreciated the work done by the student groups for their respective companies. The recommendations made by the students were also implemented in some of the companies and some companies even offered jobs to the students. The detailed feedback of the industry experts is present in Annexure 8.

\section{Student Feedback}

After the first semester, students requested the expansion of Capstone projects on more functional and operational basis along with the availability of projects for each major specialization area of the students (Marketing, Human Resource, Finance, Supply chain). On the basis of this feedback, more projects were acquired falling in different functional and operational aspects and areas of specialization. Detailed feedback of the students is present in Annexure 9.

\section{Conclusion}

Currently IoBM is not charging anything from the companies for the research services being provided by its MBA students. The experience of capstone project course benefits not just the students but also the company through the provision of new and unbiased market insights gathered by the students on behalf of the company. The students deliver in-depth analysis and recommendation for the company's decision making on the designated task. At the same time Capstone Project provides an opportunity to the students to engage with real world complexities, enhance individual competencies and develop lasting skills most importantly in thinking and analysis, communication, managing information and decision making. This also helps the students to review current understanding and assess alternate approaches to the identified problem applying theoretical and conceptual framework (well researched) and demonstrating a capacity for evaluation and critical thinking. IoBM has started to receive consultancy projects from different companies because of Capstone project course. Furthermore, IoBM is planning to open a consultancy center for the graduates and companies to collaborate.

\section{References}

1. Howe, S., Wilbarger, J., 2005. National Survey of Engineering Capstone Design Courses, in: Proceedings of the 2006 ASEE Annual Conference and Exposition. pp. 1821.

2. Kolb, D., 1984. Experiential Education: Experience as the Source of Learning and Development. Englewood Cliffs, NJ: Prentice Hall.

3. Kolb, D.A., Fry, R.E., 1974. Toward an Applied Theory of Experiential Learning. MIT Alfred P. Sloan School of Management.

4. McCarthy, P.R., McCarthy, H.M., 2006. When Case Studies Are Not Enough: Integrating Experiential Learning into Business Curricula. J. Educ. Bus. 81, 201204.

5. Mintzberg, H., 2004. Managers, not MBAs: A Hard Look at the Soft Practice of Managing 
and Management Development. BerrettKoehler Publishers.

6. Paris, K., Mason, S., 1995. Planning and Implementing Change for School-to-Work Transition. Madison Univ. Wis. Cent. Educ. Work.

7.Smith, M.K., 2001. David A. Kolb on Experiential Learning. Infed. org.

\section{Annexure 1}

November 8, 2016

Mr. ABC

Head Product Development

XYZ Company

Karachi

\section{Final Year MBA Capstone Project on an Industry Issue}

Dear Sir/Madam,

CBM's MBA program is focused on developing a real life understanding of problems and issues of industry and organizations in Pakistan through experiential learning projects. The final year project of the MBA students provides them with an intensive real life exposure of studying and resolving an issue or problem faced by an industry organization. Your organization can benefit from the deployment of one or more of our student groups for a project requiring research, fieldwork, analysis and alternatives.

IoBM invites you to engage one or more of our student groups to conduct an in-depth analysis of an issue that your company would like to investigate and present their findings and recommendations. Please note that the final year MBA Capstone Project is spread over two semesters with an expected student effort of 1500 man-hours. Each project will be assigned to a student group who will complete the project under the close supervision of IoBM Faculty.

This experience will benefit the company through the provision of new and unbiased market insights gathered by the students on behalf of the company. The students will also deliver in-depth analysis and recommendation for company's decision making on the designated task. At the same time Capstone Project provides an opportunity to the students to engage with real world complexities, enhance individual competencies and develop lasting skills most importantly in thinking and analysis, communication, managing information and decision making. This will also help them to review current understanding and assess alternate approaches to the identified problem applying theoretical and conceptual framework (well researched) and demonstrating a capacity for evaluation and critical thinking. Please also note that the information obtained during the completion of each project will be treated as highly confidential.

We are currently in the process of registering new Capstone projects for the coming semester (Spring 2017), which will commence from January 2017. For this purpose we would like to invite your organization to provide us with a project. We hope that this proposal will be of immense interest to you. We are enclosing a Project Proposal form which may be filled from your side and sent to us as soon as possible.

Marium Mateen Khan \& Mohammad Ekhlaque Ahmed (2018), Journal of e-Learning and Higher Education, DOI: $10.5171 / 2018.412705$ 
The list of projects done so far by the students of IoBM with their project details is attached. During the period from summer 2015 till date (Fall 2016), the students of IoBM have completed over 100 projects with around 60 national and international companies.

Should you need any further information on this subject, please feel free to contact our Capstone Project Coordinator, Ms. LMN, (Imn@institute.com Cell\# xxxx-xxxxxxx).

Sincerely yours,

EFG (Lead Capstone Projects, OPQ institute) 


\section{Annexure 2}

\section{Institute Of Business Management Capstone Course for Mba Program Project Proposal 2017}

1- Name of the Company:

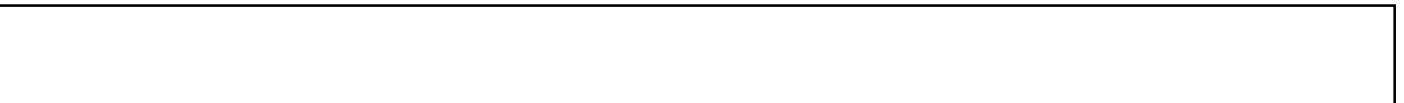

2- Name of the Contact Person(s): (Names, designations, cell no, email id)

3- Name of the Project Owner: (Name, designation, cell no, email address). The Project Owner must be different from the Contact Person)

4- Project Description: (Please describe project in brief, giving objectives, details of the issue(s), stakeholders, departments affected, scope of work, expected outcome and any other related information)

Note: If you wish to propose more than one project, please use separate form for each project. Please send the form to the following project supervisor / faculty of the Institute at your earliest. 
Annexure 3

Capstone Meeting Log Form

Semester_ Registered: $\square \mathrm{Y} \quad \square \mathrm{N}$

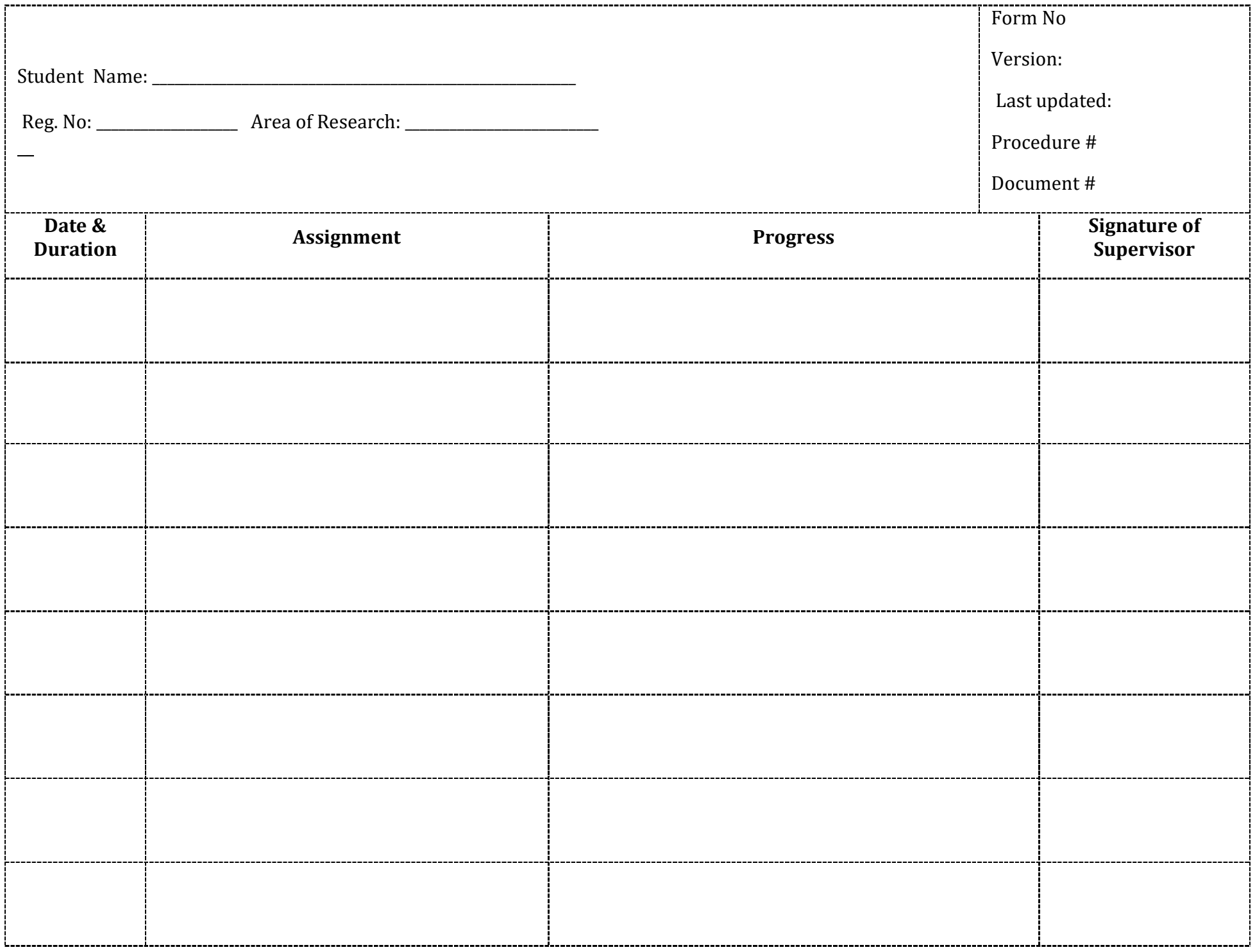

Marium Mateen Khan \& Mohammad Ekhlaque Ahmed (2018), Journal of e-Learning and Higher Education, DOI: $10.5171 / 2018.412705$ 
Annexure 4

Capstone Project Plan Form for Organization:

\begin{tabular}{|c|c|c|c|}
\hline Project Name & & & \\
\hline Student Name/Ph \# & $\begin{array}{l}1 . \\
2 . \\
3 .\end{array}$ & $\begin{array}{l}4 . \\
5 .\end{array}$ & \\
\hline $\begin{array}{l}\text { Contact Person Name } \\
\text { Designation/Ph\#/Emai }\end{array}$ & & & \\
\hline $\begin{array}{l}\text { Project Objective/ } \\
\text { Problem Statement/ } \\
\text { Decision Requirement }\end{array}$ & & & \\
\hline Deliverables and & Deliverable & & Deadline \\
\hline & 1. & & \\
\hline & 2. & & \\
\hline & 3. & & \\
\hline & 4. & & \\
\hline & 5 & & \\
\hline Research Methodology & $\begin{array}{l}1 . \\
2 . \\
3 . \\
4 . \\
5 .\end{array}$ & & \\
\hline $\begin{array}{l}\text { Secondary Research } \\
\text { Sources }\end{array}$ & $\begin{array}{l}1 . \\
2 . \\
3 . \\
4 .\end{array}$ & & \\
\hline
\end{tabular}

Marium Mateen Khan \& Mohammad Ekhlaque Ahmed (2018), Journal of e-Learning and Higher Education, DOI: $10.5171 / 2018.412705$ 


\begin{tabular}{|l|l|}
\hline $\begin{array}{l}\text { Primary Research } \\
\text { population/sample }\end{array}$ & $\begin{array}{l}\text { Population: } \\
\text { Sample: } \\
\text { Sampling Strategy: }\end{array}$ \\
\hline $\begin{array}{l}\text { \# and Type of Interviews, } \\
\text { Questionnaires, Focus } \\
\text { groups \& methodology }\end{array}$ & \\
\hline Research Questions & $\begin{array}{l}1 . \\
2 . \\
\end{array}$ \\
& 3. \\
\hline
\end{tabular}




\section{Annexure 5}

\section{Capstone Presentation Assessment Scoring Sheet (Group Grading)}

Date:

Group Project Name: Evaluator Name:

Evaluator Affiliation: $\quad \square$ Project Supervisor $\quad \square$ IoBM Expert Panel $\quad \square$ Project Client $\square$ External Expert

Term: $\square$ SPRING

$\square$ SUMMER

$\square$ FALL

Year: -

$\square$ Capstone I

Capstone II

\begin{tabular}{|c|c|c|c|c|c|}
\hline \multicolumn{6}{|c|}{$\begin{array}{l}\text { otal for each section (I, II..) in the Scor } \\
\text { cores to get Total Score. Awarded scor }\end{array}$} \\
\hline \multicolumn{2}{|r|}{ 1) Communication Skills } & $\begin{array}{c}\text { Fails to } \\
\text { Meet } \\
\text { Criterio } \\
\text { n }\end{array}$ & $\begin{array}{c}\text { Meets } \\
\text { Criterio } \\
\mathrm{n}\end{array}$ & $\begin{array}{c}\text { Exceeds } \\
\text { Criterio } \\
n\end{array}$ & Score \\
\hline \multicolumn{6}{|c|}{ I. Speaking } \\
\hline & A. Team spoke clearly and distinctly throughout & 1 & 2 & 3 & \\
\hline & B. Team spoke with confidence and with appropriate tempo & 1 & 2 & 3 & \\
\hline \multicolumn{6}{|c|}{ II. Delivery } \\
\hline & $\begin{array}{l}\text { A. All team members remained attentive and engaged with the } \\
\text { audience, even when not presenting }\end{array}$ & 1 & 2 & 3 & \\
\hline & B. Delivery medium chosen was appropriate and effective & 1 & 2 & 3 & \\
\hline & C. Team listened effectively to adequately address questions & 1 & 2 & 3 & \\
\hline 2 & \multicolumn{5}{|l|}{ Content } \\
\hline \multicolumn{6}{|c|}{ III. Organization / Preparation } \\
\hline & A. Introduction effectively communicated presentation goals & 1 & 2 & 3 & \\
\hline & B. Topic was well focused \& appropriate & 1 & 2 & 3 & \\
\hline & $\begin{array}{ll}\text { C. } & \text { Project deliverables were clearly explained } \\
\end{array}$ & 1 & 2 & 3 & \\
\hline & D. Conclusion summarized ideas well & 1 & 2 & 3 & \\
\hline \multicolumn{6}{|c|}{ IV. Project Deliverables } \\
\hline & A. Project work addressed the business problem at hand & 1 & 2 & 3 & \\
\hline & $\begin{array}{l}\text { B. Project deliverables account for the time spent on the } \\
\text { project }\end{array}$ & 1 & 2 & 3 & \\
\hline & C. Project delivered value to the client organization & 1 & 2 & 3 & \\
\hline & $\begin{array}{l}\text { D. Evidence of research and fieldwork available and well } \\
\text { documented }\end{array}$ & 1 & 2 & 3 & \\
\hline & E. $\quad$ Evidence of research and fieldwork available and well & 1 & 2 & 3 & \\
\hline
\end{tabular}

Marium Mateen Khan \& Mohammad Ekhlaque Ahmed (2018), Journal of e-Learning and Higher Education, DOI: $10.5171 / 2018.412705$ 


\begin{tabular}{|l|l|l|l|l|l|}
\hline & documented & & & & \\
\hline & F. Overall Performance of Team & 1 & 2 & 3 & \\
\hline & Total Score & & & & \\
\hline
\end{tabular}

Evaluator Signature:

Date: $-$

\section{Student Performance Evaluation (To be filled by Project Supervisor Only)}

Student Name:

Student ID:
Supervisor Name:

Organization:

Date:

\begin{tabular}{|c|c|c|c|}
\hline Term: $\square$ SPRING & 口SUMMER & $\square$ FALL & Year: \\
\hline$\square$ Capstone I & $\square$ Capstone II & & \\
\hline
\end{tabular}

\section{Guidelines}

The scales measure the behaviours and abilities that all capstone students are expected to progressively attain and refine through the capstone projects

\section{Development Required (1-2)}

Students performing within this range require further development and support to meet the performance expectations with respect to output, quality standards, delivery of goals and/or assignments.

Grade Equiv.: F-D - C- or C

\section{Development Required (1-2)}

Students performing within this range are meeting and, in some instances, exceeding the performance expectations in respect to output, quality standards, and delivery of goals and/or assignments.

\section{Superior Performance (6-7)}

Students performing within this range are consistently exceeding the performance expectations and they should be demonstrating the ability to take on broader responsibilities and team leadership roles

Grade Equiv.: A- - A - A+

\section{EXAMPLE}

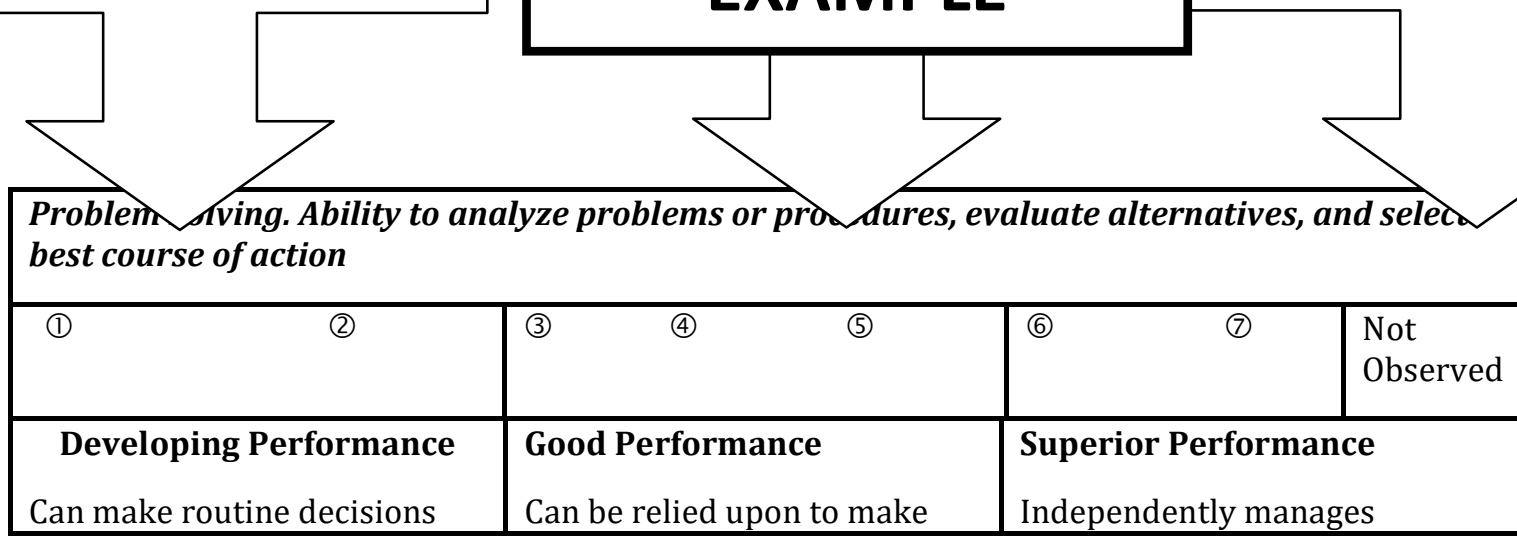

Marium Mateen Khan \& Mohammad Ekhlaque Ahmed (2018), Journal of e-Learning and Higher Education, DOI: $10.5171 / 2018.412705$ 


\begin{tabular}{|l|l|l|}
\hline $\begin{array}{l}\text { but needs ongoing guidance } \\
\text { and checking }\end{array}$ & $\begin{array}{l}\text { good decisions, requires } \\
\text { limited guidance }\end{array}$ & $\begin{array}{l}\text { complex tasks and makes good } \\
\text { decisions for work without } \\
\text { guidance }\end{array}$ \\
\hline
\end{tabular}

1. Interest in Work. The degree to which the student pursues goals with commitment and takes pride in accomplishments.

\begin{tabular}{|c|l|l|l|}
\hline \multicolumn{1}{|c|}{ (2) } & (3) (4) & (6) & $\begin{array}{l}\text { Not } \\
\text { Observed }\end{array}$ \\
\hline \multicolumn{1}{|c|}{ Developing Performance } & \multicolumn{1}{|c|}{ Good Performance } \\
$\begin{array}{l}\text { Shows little enthusiasm for } \\
\text { assigned work, infrequently } \\
\text { requests additional tasks }\end{array}$ & $\begin{array}{l}\text { Enthusiastic about their } \\
\text { assignments/work, agreeable } \\
\text { to new responsibilities, asks } \\
\text { for new tasks }\end{array}$ & $\begin{array}{l}\text { Superior Performance } \\
\text { Displays enthusiasm for work } \\
\text { that is beyond their job } \\
\text { requirements; proactively seeks } \\
\text { new tasks and responsibilities }\end{array}$ \\
\hline
\end{tabular}

2. Ability to Learn. The extent to which the student becomes proficient with job duties and work processes.

\begin{tabular}{|l|l|l|l|}
\hline \multicolumn{1}{|c|}{ (2) } & (3) (4) & (6) & \multicolumn{1}{c|}{$\begin{array}{l}\text { (7) } \\
\text { Observed }\end{array}$} \\
\hline \multicolumn{1}{|c|}{$\begin{array}{l}\text { Developing Performance } \\
\begin{array}{l}\text { Sometimes slow to become } \\
\text { proficient at new tasks or } \\
\text { work processes }\end{array}\end{array}$} & $\begin{array}{l}\text { Good Performance } \\
\text { Quick to become proficient at } \\
\text { new tasks }\end{array}$ & $\begin{array}{l}\text { Superior Performance } \\
\text { Exceeds expectations in the } \\
\text { complexity and difficulty of } \\
\text { work they are able to } \\
\text { successfully complete }\end{array}$ \\
\hline
\end{tabular}

3. Quality of Work. The ability of the student to set high standards for their own personal performance; strive for quality work; put forth extra effort to ensure quality work (includes oral and written communication).

\begin{tabular}{|c|l|l|l|l|}
\hline (1) (2) & (3) & (6) & $\begin{array}{l}\text { Not } \\
\text { Observed }\end{array}$ \\
\hline $\begin{array}{c}\text { Developing Performance } \\
\text { Work does not meet } \\
\text { expectations, has more than } \\
\text { the expected number of errors }\end{array}$ & $\begin{array}{l}\text { Good Performance } \\
\text { Work is usually very thorough } \\
\text { and well done, few errors }\end{array}$ & $\begin{array}{l}\text { Superior Performance } \\
\text { Work is always very thorough } \\
\text { and of excellent quality, few if } \\
\text { any errors }\end{array}$ \\
\hline
\end{tabular}

4. Quantity of Work. The volume of work produced by the student, along with his or her speed and consistency of output.

\begin{tabular}{|c|l|l|l|}
\hline \multicolumn{1}{|c|}{ (2) } & (3) (4) & (6) & $\begin{array}{l}\text { Not } \\
\text { Observed }\end{array}$ \\
\hline $\begin{array}{c}\text { Developing Performance } \\
\text { Does not always complete }\end{array}$ & $\begin{array}{c}\text { Good Performance } \\
\text { Completes the majority of } \\
\text { work within specified }\end{array}$ & $\begin{array}{l}\text { Superior Performance } \\
\text { Consistently completes work } \\
\text { ahead of schedule; seeks }\end{array}$ \\
\hline
\end{tabular}

Marium Mateen Khan \& Mohammad Ekhlaque Ahmed (2018), Journal of e-Learning and Higher Education, DOI: $10.5171 / 2018.412705$ 


\begin{tabular}{|c|c|c|c|}
\hline work within time limits & deadlines & \multicolumn{2}{|l|}{ additional tasks } \\
\hline \multicolumn{4}{|c|}{$\begin{array}{l}\text { 5. Problem Solving. Ability to analyze problems or procedures, evaluate alternatives, and select } \\
\text { best course of action }\end{array}$} \\
\hline (1) & (3) & & $\begin{array}{l}\text { Not } \\
\text { Observed }\end{array}$ \\
\hline $\begin{array}{l}\text { Developing Performance } \\
\text { Can make routine decisions } \\
\text { but needs ongoing guidance } \\
\text { and checking }\end{array}$ & $\begin{array}{l}\text { Good Performance } \\
\text { Can be relied upon to make } \\
\text { good decisions, requires } \\
\text { limited guidance }\end{array}$ & $\begin{array}{l}\text { Superior P } \\
\text { Independently r } \\
\text { complex tasks a } \\
\text { decisions for wc } \\
\text { guidance }\end{array}$ & $\begin{array}{l}\text { mance } \\
\text { es } \\
\text { thes good } \\
\text { thout }\end{array}$ \\
\hline \multicolumn{4}{|c|}{ 6. Teamwork. The degree to which the student works well in a team setting } \\
\hline (1) & (3) & (6) & $\begin{array}{l}\text { Not } \\
\text { Observed }\end{array}$ \\
\hline $\begin{array}{l}\text { Developing Performance } \\
\text { Can make routine decisions } \\
\text { but needs ongoing guidance } \\
\text { and checking }\end{array}$ & $\begin{array}{l}\text { Good Performance } \\
\text { Can be relied upon to make } \\
\text { good decisions, requires } \\
\text { limited guidance }\end{array}$ & $\begin{array}{l}\text { Superior Perfo } \\
\text { Independently r } \\
\text { complex tasks a } \\
\text { decisions for wc } \\
\text { guidance }\end{array}$ & $\begin{array}{l}\text { ce } \\
\text { kes good } \\
\text { thout }\end{array}$ \\
\hline \multicolumn{4}{|c|}{$\begin{array}{l}\text { 7. Response to Supervision. The manner in which the student responds to direction and } \\
\text { constructive criticism }\end{array}$} \\
\hline (1) & (3) & (6) & $\begin{array}{l}\text { Not } \\
\text { Observed }\end{array}$ \\
\hline $\begin{array}{l}\text { Developing Performance } \\
\text { Sometimes disregards } \\
\text { direction and feedback from } \\
\text { supervisor }\end{array}$ & $\begin{array}{l}\text { Good Performance } \\
\text { Integrates feedback from } \\
\text { supervisor into their work to } \\
\text { improve productivity \& } \\
\text { efficiency }\end{array}$ & $\begin{array}{l}\text { Superior Perfo } \\
\text { Takes the initia } \\
\text { through on all } \mathrm{f} \\
\text { supervisor and } \\
\text { improve }\end{array}$ & $\begin{array}{l}\text { ce } \\
\text { follow } \\
\text { ck from } \\
\text { tinuously }\end{array}$ \\
\hline \multicolumn{4}{|c|}{$\begin{array}{l}\text { 8. Resourcefulness. The student's ability to develop innovative solutions and display flexibility in } \\
\text { unusual circumstances. }\end{array}$} \\
\hline (1) & (3) & (6) & $\begin{array}{l}\text { Not } \\
\text { Observed }\end{array}$ \\
\hline $\begin{array}{l}\text { Developing Performance } \\
\text { Unsure how to approach new } \\
\text { or stressful situations; has } \\
\text { difficulty adjusting to } \\
\text { changing priorities and } \\
\text { circumstances }\end{array}$ & $\begin{array}{l}\text { Good Performance } \\
\text { Responds appropriately to new } \\
\text { or stressful situations; can } \\
\text { adjust to changing priorities } \\
\text { and circumstances with } \\
\text { guidance }\end{array}$ & \multicolumn{2}{|c|}{\begin{tabular}{|l} 
Superior Performance \\
Generates effective resolutions \\
to new or stressful situations; \\
readily adjusts to changing \\
priorities and circumstances
\end{tabular}} \\
\hline
\end{tabular}

Marium Mateen Khan \& Mohammad Ekhlaque Ahmed (2018), Journal of e-Learning and Higher Education, DOI: $10.5171 / 2018.412705$ 
Project Supervisor's Comments - Please comment on student's overall performance:

Evaluation Discussed with Student:

$\square$ YES

$\square$ NO

$\square$ NOT

APPLICABLE

Do you want to supervise the student in Capstone II?

$\square$ YES

$\square$ NO

$\square$ NOT APPLICABLE

\begin{tabular}{|c|c|c|c|}
\hline $\begin{array}{c}\text { Supervisor's } \\
\text { Evaluation } \\
30 \% \text { (Individual Score) }\end{array}$ & $\begin{array}{l}\text { Weekly Progress } \\
\text { Report } \\
25 \% \text { (Individual } \\
\text { Score) }\end{array}$ & $\begin{array}{l}\text { Panel's Evaluation } \\
25 \% \text { (Group Score) }\end{array}$ & $\begin{array}{l}\text { Client's Evaluation } \\
20 \% \text { (Group Score) }\end{array}$ \\
\hline & & & \\
\hline
\end{tabular}

Overall Grade Awarded to Student:

Supervisor's Signature

Capstone Project Head Signature

Dean's

Signature

Marium Mateen Khan \& Mohammad Ekhlaque Ahmed (2018), Journal of e-Learning and Higher Education, DOI: $10.5171 / 2018.412705$ 


\section{Company Evaluation of Work Report (To be filled by Industry Supervisor Only)}

Company Name:

IoBM Supervisor Name:

Term: $\square$ SPRING

Capstone I

Evaluator Name:

Date:

$\square$ SUMMER $\quad \square$ FALL Year:

$\square$ Capstone II

As a requirement of the Capstone Project programs, students have been tasked with working towards solutions for your identified business needs. During this process, students are required to coordinate and provide you with periodic work reports. Work Reports are marked by both the Industry Supervisor (YOU) and the IoBM nominated Project Supervisor. To receive credit for the report, a student must receive acceptable or higher from both markers. Providing appropriate feedback on the subject matter of the report can be difficult for the university evaluator since the content is normally related to the work environment. Therefore, we request your assistance in this area.

Your input is greatly appreciated!

\begin{tabular}{|l|l|l|l|}
\hline $\begin{array}{l}\text { Quality of Subject } \\
\text { Matter }\end{array}$ & Poor & Average & Outstanding \\
\hline $\begin{array}{l}\text { Team's Work Ethic \& } \\
\text { Commitment to the } \\
\text { Project }\end{array}$ & & & \\
\hline $\begin{array}{l}\text { Command on } \\
\text { Technical Aspects of } \\
\text { the Project }\end{array}$ & & & \\
\hline $\begin{array}{l}\text { Team's Ability to Add } \\
\text { Value to the } \\
\text { Organization }\end{array}$ & & & \\
\hline Overall Feedback & & & \\
\hline
\end{tabular}

Industry Supervisor's Comments - Please comment on group's overall performance:

Marium Mateen Khan \& Mohammad Ekhlaque Ahmed (2018), Journal of e-Learning and Higher Education, DOI: $10.5171 / 2018.412705$ 
Do you want to continue with IoBM's Capstone Program? $\square$ YES

$\square$ NO

SURE

Overall Marks Awarded to Group: $/ 20$

\section{Annexure 6}

\section{Sample Capstone Project List}

\begin{tabular}{|c|c|c|c|}
\hline \multicolumn{4}{|c|}{ Capstone Projects Summer-2015 } \\
\hline S.No & Company Name & Department & Project Description \\
\hline 1 & Dalda Foods (1) & Marketing & Brand Strategy Development \\
\hline 2 & Dalda Foods (2) & Marketing & Gap identification and Downstream Innovation \\
\hline 3 & Abbott Pakistan & Marketing & $\begin{array}{l}\text { Model transformation from Product to Category } \\
\text { Communication }\end{array}$ \\
\hline 4 & Pharmevo & Supply Chain & Improving Supply Chain/Channel Integration \\
\hline 5 & Engro & HRM & $\begin{array}{l}\text { Public welfare development project to hire disabled } \\
\text { people. }\end{array}$ \\
\hline 6 & Hashwani Group & HRM & $\begin{array}{l}\text { Process mapping of different activities of different depts. } \\
\text { and preparing SOPs and JDs. }\end{array}$ \\
\hline 7 & $\begin{array}{l}\text { Leopards Courier } \\
\text { Pakistan }\end{array}$ & HRM & $\begin{array}{l}\text { Issues with Job satisfaction of Senior Managers and how } \\
\text { to improve it. }\end{array}$ \\
\hline 8 & $\mathrm{CDC}$ & Finance & $\begin{array}{l}\text { Reasons for low investor base in capital markets of } \\
\text { Pakistan. }\end{array}$ \\
\hline 9 & GSK & Supply Chain & Supply chain SOP for inventory and ware housing. \\
\hline 10 & GETZ Pharma & Marketing & $\begin{array}{l}\text { Develop strategies for successful penetration for health } \\
\text { care market for existing OTC products. }\end{array}$ \\
\hline 11 & TCS E-Com (Pvt.) Ltd & HRM & $\begin{array}{l}\text { Recommendation of best HR practices being followed by } \\
\text { local and international companies. }\end{array}$ \\
\hline 12 & Express News & $\begin{array}{l}\text { Media Industry } \\
\text { Research }\end{array}$ & To identify the net reach of the Channel. \\
\hline 13 & Ehtesham Packages (1) & Marketing & $\begin{array}{l}\text { Feasibility report for a reel to reel Label Printing machine } \\
\text { with online additional option. }\end{array}$ \\
\hline 14 & Pharma Industry & Supply Chain & $\begin{array}{l}\text { Issue of local production of raw materials for } \\
\text { pharmaceutical industry. }\end{array}$ \\
\hline 15 & Qindeel Academy & Process Improvement & $\begin{array}{l}\text { To develop a donor-social action plan, and develop } \\
\text { awareness campaigns. }\end{array}$ \\
\hline
\end{tabular}

Marium Mateen Khan \& Mohammad Ekhlaque Ahmed (2018), Journal of e-Learning and Higher Education, DOI: $10.5171 / 2018.412705$ 


\begin{tabular}{|c|l|c|l|}
\hline 16 & HBL & Finance/Audit & $\begin{array}{l}\text { To evaluate/gauge the effects of traditional audit } \\
\text { practices in Banking Industry. }\end{array}$ \\
\hline 17 & $\begin{array}{l}\text { Alpha container } \\
\text { industries Pvt. Ltd }\end{array}$ & Process Improvement & Suggestions for proper placement of workforce. \\
\hline 18 & Engro Foods Limited & Marketing & $\begin{array}{l}\text { New channels' identification and Market proposition for } \\
\text { new product. }\end{array}$ \\
\hline 19 & Lucky Cement & Supply chain & Suggestions for the appropriate disposal of coal ash. \\
\hline 20 & JS BANK & Finance & Impact of JS Group on Economy of Pakistan. \\
\hline
\end{tabular}

Annexure 7

\section{Capstone Checklist}

Company Name:

Faculty Supervisor:

\section{Group Members:}

\begin{tabular}{|l|l|l|}
\hline S.NO. & Item & YES/NO \\
\hline 1 & Minutes of Meetings & \\
\hline 2 & Logs for Allocation of Meetings & \\
\hline 3 & Field Notes & \\
\hline 4 & Meeting Notes & \\
\hline 5 & Capstone Project Form for Organization & \\
\hline 6 & Capstone Meeting Log Form & \\
\hline 7 & Attendance for each Corporate Meeting & \\
\hline 8 & Gantt Chart & \\
\hline 9 & Timeline Plan for each Deliverable & \\
\hline 10 & Report for each Successful Deliverable Submitted to the Company & \\
\hline 11 & Report for each Deliverable in case of any lagging in Deliverable Submission & \\
\hline 12 & Interim Final Report & \\
\hline 13 & Final Report & \\
\hline 14 & Interim Presentation & \\
\hline 15 & Final Presentation & \\
\hline
\end{tabular}

Marium Mateen Khan \& Mohammad Ekhlaque Ahmed (2018), Journal of e-Learning and Higher Education, DOI: $10.5171 / 2018.412705$ 


\title{
Annexure 8
}

\author{
Industry Experts' Comments
}

\section{Nutralake Healthcare}

It is a wonderful experience to work with final year MBA students of IoBM. I think it is a win-win situation and more productive for the students. The project makes the students aware of real situation handling in life project with the company. I really appreciate the excellent efforts.

\section{Abbott Laboratories Pakistan Limited}

The group performed well against the set guidelines whereas the delivery was also observed timely. Despite being lacked on some research aspects, they covered the shortfall in a quick succession hence their performance in the last duration of the project timeline was exemplary.

Their field work commitment considering the difficult timing w.r.t. pharmaceutical sector needs to be commended especially the females in the group as they demonstrated the conformance to the appointments and also to the interviewing principles at par with their male colleagues.

Lastly their presentation as a group was also very well appreciated at Abbott's desks where they not only transported the real and unedited insights but also showed their citizenship towards the company as a group.

\section{Wavetec - Vendi}

The group showed good commitment to the project. I would be interested in working with them for phase 2 and implementing some of their suggestions during part 1 to judge the results in a more practical environment

\section{Digitz Pvt. Ltd}

The group worked really hard in getting all the research done, full marks on that. Another noticeable thing was that they took initiatives when needed. However, their submission was not on time and the project was delayed. But all in all, it was a good effort made.

\section{Dalda Foods (Pvt.) Ltd}

The quality of research work put up by the students is commendable. We were able to cull insights from the data shared, which will serve as a part of key inputs for our business. Great job! Great effort!

\section{Online Distributions}

The team did a tremendous job. They have submitted a comprehensive report and well-defined each and every aspect of the work given. We are planning to float this SOP through them to our partners. 


\section{PharmEvo (Private) Limited}

We acknowledge the efforts of students in delivering the task assigned to them, and interacting with different groups of people to analyze the causes of given state of problem and then suggesting practical solutions.

Overall the students were able to develop and suggest a plan to reduce lead time involved in delivery of Pharmaceutical products.

We wish them best of luck in their future endeavors.

\section{Premier Agencies}

We acknowledge and appreciate the efforts of students in exhibiting the professional knowledge over the task provided to them. Overall Student's group was able to develop an insight for potential categories and the linkages between consumer buying patterns.

We wish them good luck for their project and corporate career.

\section{Zong}

Overall good effort by the group, they took the time to learn industry dynamics before conducting the research. Data collected by the students was comprehensive and useful for the brand

\section{Engro Tarang}

They have done hard work, they know their stuff, they have talked to the people to gain insights. I like what I am seeing so far done by them. I like some of the recommendations made by the students and I am looking forwards towards implementing them at Engro.

\section{Engro PWD}

The students owned the project since the start. They went in explored the areas and found far beyond what I had expected from them. The things they have highlighted are now being worked on. I wish all the students the best of luck for the future.

UBL

The IoBM students have done a tremendous job. The insights revealed in this phase were theoretical, now in the next phase we expect them to go on the practical side of the key areas highlighted.

\section{Hashwani Group}

I showed the Org Charts and Performance Appraisal documents you developed for us to the Director HR and she really liked your work and wishes me to convey her commendations. I am happy that employees at all level cooperated a lot and you handled the meetings meticulously.

We look forward to your project presentation and recommendations. It was a pleasure working with you in Capstone: 1 and are happy to continue the project to Capstone 2. The TORs you have sent look good and we look forward to doing more work with you.

\section{China Overseas Port Holding Company}

On behalf of COPHC Management, we highly appreciate the great amount of efforts put in by IOBM dedicated faculty and knowledge yearning students. Experiential Learning philosophy, initiated by 
IOBM, is undoubtedly a very effective mean of transferring knowledge and experience to students. We take pride in collaborating with IOBM in executing this mission.

We really appreciate the amount of hard work and research work that IOBM students have demonstrated during their CAPSTONE.

We certainly welcome more such projects and want to be part of IOBM agenda of shaping Business Education for future generation!

\section{Premier Agencies}

I'm very much satisfied with the efforts of students. They all have been wonderful students and a great team. I wish I had you all again in Capstone 2 for my projects!

I was surprised and delighted to see students handle the challenges of conducting surveys with the sales reps in even remote areas and present their in-depth analysis. I am particularly impressed by the integration of the Blue Ocean Strategy concepts in your analysis which has been very interesting and very informative.

\section{Dabur Pakistan}

The group should add more value in terms of Research \& way forward to launch Fem in Pakistan. 


\section{Annexure 9}

\section{Student Feedback}

\begin{tabular}{|c|c|}
\hline Positive points & Points need to be Worked on \\
\hline \multicolumn{2}{|c|}{ Was Capstone Project Course helpful for you and in what manner? } \\
\hline $\begin{array}{l}\text { Ability to learn a lot of new things which could only } \\
\text { be learned while on job }\end{array}$ & $\begin{array}{l}\text { Should be done in BBA as it will be more beneficial to } \\
\text { students aspiring for a career. . }\end{array}$ \\
\hline $\begin{array}{l}\text { Broadened the learning horizons. Also learned how } \\
\text { to process ideas and communicate effectively }\end{array}$ & $\begin{array}{l}\text { More projects of Marketing, HR and Supply chain and } \\
\text { lack of projects on Financial areas }\end{array}$ \\
\hline $\begin{array}{l}\text { A complete learning by experience, provided vast } \\
\text { knowledge of the field and practical world } \\
\text { experience }\end{array}$ & $\begin{array}{l}\text { Capstone project field work was a hassle for working } \\
\text { students. }\end{array}$ \\
\hline \multicolumn{2}{|c|}{ Which other skills were developed through Capstone Project Course? } \\
\hline $\begin{array}{l}\text { Stress management skills as we have to handle a lot } \\
\text { of pressure in this project. Along with improvement } \\
\text { in self-confidence, communication and analytical } \\
\text { skills }\end{array}$ & Project-job incompatibility \\
\hline \multicolumn{2}{|c|}{ How has the experience influenced your critical thinking and problem solving skills/abilities? } \\
\hline $\begin{array}{l}\text { Both skills have greatly improved along with time } \\
\text { management and coming up with alternative } \\
\text { solutions }\end{array}$ & $\begin{array}{l}\text { An employed student like me finds it very difficult to } \\
\text { balance capstone, job and MBA altogether }\end{array}$ \\
\hline \multicolumn{2}{|c|}{$\begin{array}{l}\text { Please share a specific example of how your experience impacted, if at all, your transition to workplace } \\
\text { and how this specific example impacted your career? }\end{array}$} \\
\hline $\begin{array}{l}\text { I am getting diverse experience and I am now more } \\
\text { confident and have enhanced analytical skills. } \\
\text { I was able to arrange training sessions on my own } \\
\text { after this experience. Also helped in transition to } \\
\text { new work place }\end{array}$ & $\begin{array}{l}\text { Even though capstone project helped in certain areas I } \\
\text { still think it's a burden on students who are working and } \\
\text { have to meet deadlines of capstone project too }\end{array}$ \\
\hline \multicolumn{2}{|l|}{ How can the mentoring sessions be improved? } \\
\hline $\begin{array}{l}\text { Our mentor was extremely helpful during the } \\
\text { project. He has been a great luminary. He assisted } \\
\text { us, guided us and motivated throughout. I really } \\
\text { enjoyed being mentored by him }\end{array}$ & $\begin{array}{l}\text { Work should be acknowledged when it's done right. } \\
\text { Timings of interaction for capstone should be made } \\
\text { feasible for students specially those who work }\end{array}$ \\
\hline
\end{tabular}

Marium Mateen Khan \& Mohammad Ekhlaque Ahmed (2018), Journal of e-Learning and Higher Education, DOI: $10.5171 / 2018.412705$ 